\title{
Construction of Latent Hypotheses on Collaborative Learning from the Perceptions of Future Educators
}

\author{
Bartolomé Vázquez-Bernal and Roque Jiménez-Pérez \\ University of Huelva, Huelva (Andalusian), Spain
}

\author{
bartolome.vazquez@ddcc.uhu.es riimenez@uhu.es
}

\begin{abstract}
This work analyses the perceptions of future teachers at both primary education and secondary/university level, in relation to the use of virtual collaborative learning platforms. The collaborative working method was different at each level, in line with students' course requirements, skills, access to technology and the time available. An attitudes-based evaluation instrument was developed to assess student perceptions of the collaborative learning tool Synergeia, after which statistical methods, especially factor analysis, were used to identify and elaborate on latent underlying structures. A number of hypotheses were then developed to explain the differences in perception between the two groups. Student perceptions appear to fall into categories that can be designated as either epistemological or methodological relativism, and demonstrated the need for a certain degree of caution towards the use of virtual learning. The implications of this research included the need for continuous training in the ICT area for future educators.
\end{abstract}

Keywords: Collaborative learning, improving classroom teaching, interactive learning environments, pedagogical issues, teaching/learning strategies.

\section{Introduction}

The use of virtual learning environments in university education has changed the relationship between teachers and students. More independent and reflective learning by students, together with collaborative support found in small groups, leads to better learning outcomes (Rodríguez, Infante, \& Pardo, 2004). From the viewpoint of teachers, the new dynamic employs reflection and metacognition to increase student control of their own learning and, as a result, the level of classroom intervention by teachers is reduced (Mellado, Ruiz, Bermejo, \& Jiménez, 2006). The introduction of new Information and Communication Technologies (ICTs) in the educational sphere has thus served to introduce a new culture of knowledge construction within learning communities, creating synergies between collaborative and independent learning experiences (Lipponen, Rahikainen, Hakkarainen, \& Palonen, 2002).

Material published as part of this publication, either on-line or in print, is copyrighted by the Informing Science Institute.

Permission to make digital or paper copy of part or all of these works for personal or classroom use is granted without fee provided that the copies are not made or distributed for profit or commercial advantage AND that copies 1) bear this notice in full and 2) give the full citation on the first page. It is permissible to abstract these works so long as credit is given. To copy in all other cases or to republish or to post on a server or to redistribute to lists requires specific permission and payment of a fee. Contact Publisher@,InformingScience.org to request redistribution permission.
The aim of this work is to investigate how exposure to collaborative learning software can help to develop education students' awareness of their own learning process; and from there to assess how this changed perspective can in turn influence their future use of ICTs as tools for knowledge construction (Vázquez-Bernal, 2010). 


\section{Literature Review}

Collaborative learning is the didactic use of small groups in which students work together to achieve the best learning outcomes both individually and in groups. It is not only a set of steps for working in an orderly way in a group; it is a philosophy of life, in which the participants are aware that the whole group is more than the sum of its parts (Vygotsky, 1978). The advantages of collaborative learning are multiple and outweigh the difficulties that arise from its implementation (Bower \& Richards, 2006), with the following among the benefits:

- Stimulating personal abilities (Kolodner \& Guzdial, 1996).

- Reducing feelings of isolation (Dillenbourg, 1999).

- Favouring feelings of self-sufficiency (Pardo, Morales, \& Rodríguez, 2009).

- Encouraging, on the basis of individual participation, shared responsibility for group outcomes (Roschelle \& Teasley, 1995).

- Enabling the achievement of learning objectives that are richer in content, with improved quality and rigour in the ideas and solutions proposed (Baghaei, Mitrovic, \& Irwin, 2007).

- Propitiating the generation of knowledge, as students are involved in carrying out research where their contribution adds value, and they no longer remain merely passive receivers of information (Stahl, Koschmann, \& Suthers, 2006).

Heo, Lim, \& Kim, Y. (2010) have shown the importance of negotiation skills and knowledge coconstruction for cohesion and learning in collaborative groups. Computer-supported collaborative learning (CSCL) is destined to play an increasingly important role in education and is seen as one of the most promising pedagogical paradigms (Rubens, 2003). According to Lafifi and Touil (2010), peer-to-peer collaboration among teachers has a positive effect on the cognitive profile of their students.

An international study on the perceptions of teachers in initial training towards the integration of technology in education brings to light interesting aspects (Koksal \& Yaman, 2009). Their investigation into the role played by students' computer skills and learning styles found that there is a significant relationship between levels of computer competency and students' perceptions of technology in education. However, they found no significant association between different learning styles and students' beliefs about technology in education.

Ćukušić, Alfirevic, Granić, \& Garača (2010) demonstrated the existence of a clear link between planning and controlling of the e-learning process and its learning outcomes, but found no evidence of any relationship between e-learning outcomes and the subject of learning in terms of pedagogical content. On the other hand, despite increases in computer access and technology training, Ertmer and Ottenbreit-Leftwich (2010) think that technology is not being used to support the kinds of instruction believed to be most powerful (student-centered) and they propose that teachers' mindsets must change to include the idea that teaching is not effective without the appropriate use of ICT resources to facilitate student learning.

The construction of new knowledge through collaborative learning relies on a shared means of communication (language), a joint focus (object-orientation), and a compatible orientation (perspective) (Stahl \& Hesse, 2009). In addition, van Aalst (2009) distinguishes three modes of discourse, which correspond to three established theoretical perspectives:

- Knowledge sharing, which is based on a transmission theory of communication.

- Knowledge construction, which is based on cognitive psychology (constructivism)

- Knowledge creation, which is based on interactive learning mediated by shared objects. 
In our study these different perspectives are implicit. In turn, Stahl and Hesse (2009) extend the definition of shared knowledge to encompass the sharing of an individual mental representation, an object, a community and a situation. We are situated in this last paradigm, where a group can share knowledge by being situated in a common context. Another interesting aspect arises from the idea of a tripartite division into macro, meso and micro levels, which has been developed in the field of complex systems by Liljenström and Svedin (2005).

On another level, Jones and Dirckinck-Holmfeld (2009) think that CSCL is a classic example of a complex system with non-linear interrelationships between variables, including thresholds, lags and discontinuities. Those authors argue that it is necessary to focus on what they have called the meso level of collaborative learning. We are in accord with such thinking, and our work has been mainly focused on how to design for collaborative learning at the institutional level, identifying the basic conditions that allow for collaborative learning. In addition, we seek to understand how technologies and infrastructures afford and mediate the learning taking place.

An emergent and equally interesting aspect of CSCL relates to critical thinking skills. Given the speed at which technology changes in the digital world, these skills are important for the careers for which students are being prepared; without these skills, student will be severely disadvantaged when adapting to innovations in technology (Morin, Thomas, \& Saadé, 2012). All of these aspects are critical in today's learning process, especially with the integration of computer supported technologies. Hence the need for knowledge acquisition and transfer, as well as knowledge construction, meaning negotiation, questioning shared values, and challenging taken-for-granted assumptions (Huynh, Lee, \& Schuldt, 2005). Ma (2012), in a recent study, has used an analytical framework to examine the relationship between CSCL and critical reflective capabilities. His findings revealed that high levels of social interaction and collaboration contributed to the establishment of a community of reflective learners. This has created a space for promoting critical reflective capabilities and has facilitated the co-creation of new understandings and interpretations leading to transformative outcomes.

Finally, we cannot ignore some of the challenges that must be overcome when working with elearning projects, including the frustrations of being overworked and overwhelmed that are commonly associated with technical problems (Smith \& Greene, 2013). This latter issue has emerged in studies showing certain reservations in nascent educators, who are aware of the need to evolve, but question their own ability to deal with the use of virtual platforms in daily situations (Silveira \& Madrid, 2009).

\section{The Case of Synergeia}

The ITCOLE project (Innovative Technologies for Collaborative Learning) is supported by the European Union. A special feature of the project is that both the pedagogical models and the software tools developed are distributed free of charge. The teaching-learning model behind it is framed in a "Progressive Research Model", a heuristic frame to structure and support the progress of the students and their epistemological skills in the construction of knowledge (http://www.euro-scl.org/site/itcole/itcole_brochure.pdf).

The aim of the ITCOLE project is to create "Student Communities" where computers and networks can be used to develop and maintain communities working remotely. The idea is founded on a co-constructivist model, in which a framework, designated "Synergeia", becomes a virtual tool. Synergeia is an extension of BSCW (Basic Support for Cooperative Work), created in Germany in 1995 by the Fraunhofer-Institut für Angewandte Informationstechnik (FIT) (http://bscl.fit.fraunhofer.de/en/about.html). 
The Synergeia software consists of two main components:

a) Asynchronous communication and collaboration based on BSCL software (Basic System for Collaborative Learning).

b) Synchronous communication and collaboration based on MapTool and instant messaging software (Chat).

The essential aims of Synergeia as a collaborative framework are:

a) The construction of virtual work spaces.

b) Familiarising students with ICT and telematic frameworks for future implementation as qualified educators.

c) Shared knowledge construction.

d) Generation of negotiation skills in knowledge construction.

e) Stimulating criticism and evaluation of theories and explanations.

f) Encouraging the future participation of pupils in the knowledge society.

\section{Methodology}

\section{Aims of the Work}

The objectives of the present work are:

a) To prepare an attitudes-based instrument for evaluating the Synergeia tool.

b) To analyse differences in the perceptions of Synergeia between groups of students using different learning frameworks in order to identify underlying hypotheses.

\section{Sample Features}

The participants in this study were two groups of students attending university courses that focused on professional development in education. The two courses that provided the material for this study were at different educational levels and involved the use of different learning frameworks.

The first group was made up of 20 students doing a university degree course in Primary Education (future teachers for pupils 6 to 12 years). The subject that was selected for the study is a component adapted to the EHEA (European Higher Education Area), worth 4.5 ECTS (European Credit Transfer System) credits. The subject is designated Basic Techniques for Research and Awareness of the Natural Environment, taking as reference the Active Learning Methodologies (ALM) approach. ALM stems from what is termed the Seventh Framework Programme (20072013) of the European Commission to Construct the Europe of Knowledge. Within the ALM, the work was carried out in a variant termed Collaborative Learning, already described in the theoretical frame. The pupils were working on minor research projects into different aspects of natural sciences: physics, chemistry, biology and geology. The aim was to develop technical skills related to knowledge and know-how (scholastic science skills and knowledge domain). Moreover, we were interested in social skills linked with knowing how to learn and savoir faire (motivations, values and the ability to relate in an organised social context). The Synergeia virtual working environment seemed appropriate, since this type of remote framework supports knowledge construction and sharing between pupils and provides an opportunity for opening up debates on the basis of negotiation and criticism. Being oriented towards students in teacher training, the aim is to create groups of future teachers who are equipped for 21 st century education and the knowledge society (Monereo, 2004).

The second group of participants consisted of 20 students with an average age of 30 . Their educational backgrounds were diverse: primary education teachers, graduates in chemical sciences, bi- 
ology and history, doctors in biology, senior engineers and math graduates. They were taking part in an accredited Master's degree course adapted to the EHEA, entitled Master in Research in Education and Learning of Experimental, Social and Mathematical Sciences. The specific subject that was used for this research is designated Data Treatment and counts for 3 credits. The students, through practical cases, enhance their skills in using two computer data treatment programs: SPSS (quantitative data) and AQUAD (qualitative data). Although the students' work was basically "individual", the decision was taken to use the Synergeia virtual framework, mainly to provide access to all the documentation, to support centralised communications, and to enable creation of discussion forums. In contrast to the first group, each student had their own specific computer station. However, continuous interaction with the teaching staff and among pupils was encouraged.

Table 1 shows the differences between the two groups of students with regard to the elements of Synergeia that they used.

Table 1: Differences in Use of Synergeia by the Two Groups of Students

\begin{tabular}{|c|c|c|}
\hline Synergeia Elements Used & $\begin{array}{c}\text { Teacher Training } \\
\text { Students }\end{array}$ & $\begin{array}{c}\text { Master/Doctorate } \\
\text { Students }\end{array}$ \\
\hline Downloading/storing documentation & YES & YES \\
\hline Knowledge construction forums or spaces & YES & NO \\
\hline "Map Tool" cooperative screen & YES & NO \\
\hline Work negotiation (virtual) & NO & NO \\
\hline Calendar and address book management & YES \\
\hline
\end{tabular}

Both groups were trained in use of the Synergeia framework during the initial stage of their courses. The difference in the use of Synergeia elements is based on the time that was available to each group of students, since the first course counted for 4 ECTS credits and the second only 2 credits. It was also decided not to include virtual work negotiation in either of the present courses; we intend doing so in the next course offerings, in order to provide interannual contrast elements.

\section{Information Gathering Instrument}

The information gathering instrument is shown in Table 2 . The use of rating scales by students, in its most general expression and in any learning context, has proved to be effective in increasing attitudes related to metacognition (Mertler, 2001); it encourages greater autonomy and improves students' insights into their own critical thinking strengths and weaknesses (Wolcott, 2006). This supposition was incorporated into the current research design through the use of progressive hypothesis criteria, ranging from an initial 'deficit' level to a reference level coherent with our vision of desirable development outcomes (Ferreras \& Wamba, 2008). Student progress within this scale can be measured by teaching staff (in this case the researchers) based on student interactions recorded by Synergeia (Jiménez and Llitjós, 2006; Jiménez, Núñez, \& Llitjós, 2006).

Previous studies have demonstrated that teachers find it difficult to assess changing student attitudes resulting from the use of virtual cooperative learning environments (Kollias, Mamalougos, Vamvakoussi, Lakkala, \& Vosniadou, 2005). For this reason a data gathering instrument was developed that focused on six essential aspects of the new digital attitudes characterised by Synergeia. This was structured as a metacognitive instrument that would encourage reflection by the trainee teachers about their attitudes to the possible future use of cooperative learning environ- 
ments. In Table 2, each of the six key attitudes is assigned to a variable which could be rated on a scale of 1-4 based on the degree to which students are likely to incorporate each of these aspects in their future teaching careers.

Table 2: Synergeia Attitudes-Based Assessment Information Gathering Instrument

\begin{tabular}{|c|c|c|c|c|}
\hline & $\begin{array}{c}\text { Low } \\
\text { Rating } \\
1\end{array}$ & $\begin{array}{c}\text { Average } \\
\text { Rating } \\
2\end{array}$ & $\begin{array}{c}\text { Good } \\
\text { Rating } \\
3\end{array}$ & $\begin{array}{c}\text { Excellent } \\
\text { Rating } \\
4\end{array}$ \\
\hline $\begin{array}{c}\text { Learning of ICT and } \\
\text { remote frameworks as } \\
\text { students for future im- } \\
\text { plementation as teachers } \\
\text { (LEARN) }\end{array}$ & $\begin{array}{l}\text { Not planning to ap- } \\
\text { ply ICTs and remote } \\
\text { frameworks as } \\
\text { teacher in the future }\end{array}$ & $\begin{array}{l}\text { Idea of applying } \\
\text { ICTs and remote } \\
\text { frameworks as } \\
\text { teacher in the future } \\
\text { seems attractive }\end{array}$ & $\begin{array}{c}\text { Applying ICTs } \\
\text { and remote frame- } \\
\text { works as teacher in } \\
\text { the future is inter- } \\
\text { esting }\end{array}$ & $\begin{array}{l}\text { Likelihood of ap- } \\
\text { plying ICTs } \\
\text { and remote frame- } \\
\text { works as teacher in } \\
\text { the } \\
\text { future is excellent }\end{array}$ \\
\hline $\begin{array}{c}\text { Construction of virtual } \\
\text { work spaces } \\
\text { (SPACE) }\end{array}$ & $\begin{array}{c}\text { Construction of vir- } \\
\text { tual work spaces not } \\
\text { valued }\end{array}$ & $\begin{array}{c}\text { Construction of } \\
\text { virtual work spaces } \\
\text { valued somewhat }\end{array}$ & $\begin{array}{c}\text { Construction of } \\
\text { virtual work spaces } \\
\text { rated positively }\end{array}$ & $\begin{array}{l}\text { Construction of } \\
\text { virtual work } \\
\text { spaces rated } \\
\text { very positively }\end{array}$ \\
\hline $\begin{array}{l}\text { Stimulating criticism } \\
\text { and evaluation of theo- } \\
\text { ries and explanations } \\
\text { (CRITIC) }\end{array}$ & $\begin{array}{l}\text { Opposed to criticism } \\
\text { and evaluation of } \\
\text { theories and expla- } \\
\text { nations }\end{array}$ & $\begin{array}{c}\text { Accepts criticism } \\
\text { and evaluation of } \\
\text { theories and expla- } \\
\text { nations }\end{array}$ & $\begin{array}{c}\text { Values criticism } \\
\text { and evaluation of } \\
\text { theories and expla- } \\
\text { nations }\end{array}$ & $\begin{array}{l}\text { Stimulating criti- } \\
\text { cism and evaluation } \\
\text { of theories and ex- } \\
\text { planations }\end{array}$ \\
\hline $\begin{array}{l}\text { Construction of shared } \\
\text { knowledge } \\
\text { (KNOWL) }\end{array}$ & $\begin{array}{l}\text { Opposed to con- } \\
\text { struction of shared } \\
\text { knowledge }\end{array}$ & \begin{tabular}{|} 
Expresses agree- \\
ment with construc- \\
tion of shared \\
knowledge
\end{tabular} & $\begin{array}{c}\text { Values construction } \\
\text { of shared knowl- } \\
\text { edge in students }\end{array}$ & $\begin{array}{c}\text { Will induce con- } \\
\text { struction of shared } \\
\text { knowledge in stu- } \\
\text { dents }\end{array}$ \\
\hline $\begin{array}{c}\text { Generation of negotiat- } \\
\text { ing skills in knowledge } \\
\text { construction } \\
\text { (NEGOT) }\end{array}$ & $\begin{array}{l}\text { Rules out generating } \\
\text { negotiating skills in } \\
\text { knowledge construc- } \\
\text { tion }\end{array}$ & $\begin{array}{l}\text { Agrees to generate } \\
\text { negotiating skills in } \\
\text { knowledge con- } \\
\text { struction }\end{array}$ & $\begin{array}{l}\text { Values the genera- } \\
\text { tion of negotiating } \\
\text { skills in knowledge } \\
\text { construction }\end{array}$ & $\begin{array}{l}\text { Promotes genera- } \\
\text { tion of negotiating } \\
\text { skills } \\
\text { in knowledge con- } \\
\text { struction }\end{array}$ \\
\hline $\begin{array}{c}\text { Fomenting student par- } \\
\text { ticipation in knowledge } \\
\text { society } \\
\text { (PARTIC) }\end{array}$ & $\begin{array}{l}\text { Will not encourage } \\
\text { student participation } \\
\text { in knowledge } \\
\text { society }\end{array}$ & $\begin{array}{l}\text { Supports student } \\
\text { participation in } \\
\text { knowledge } \\
\text { society }\end{array}$ & $\begin{array}{c}\text { Encourages student } \\
\text { participation in } \\
\text { knowledge } \\
\text { society }\end{array}$ & $\begin{array}{l}\text { Will actively de- } \\
\text { velop student par- } \\
\text { ticipation in knowl- } \\
\text { edge } \\
\text { society }\end{array}$ \\
\hline
\end{tabular}

\section{Results}

\section{General Descriptor Results}

The results obtained for each variable are shown in Table 3 (the ratings were provided by the students themselves, based on self-reflection and metacognition), using two general descriptors: the average values and corresponding standard deviations. They are presented in two separate series, for the Teacher Training student group and the Master/Doctorate student group. Maximum and minimum values within each series are also indicated. 


\begin{tabular}{|l|c|c|c|c|}
\hline \multicolumn{4}{|c|}{ Table 3: Group 1 and 2 Results Obtained } \\
\hline \multirow{2}{*}{} & \multicolumn{3}{|c|}{$\begin{array}{c}\text { Group 1 } \\
\text { (Teacher Training Students) }\end{array}$} & \multicolumn{2}{c|}{$\begin{array}{c}\text { Group 2 } \\
\text { (Master/Doctorate Students) }\end{array}$} \\
\cline { 2 - 5 } & Average value & Std. Deviation & Average value & Std. Deviation \\
\hline LEARN & 3.59 & 0.503 & 3.55 & 0.510 \\
\hline KNOWL & $3.41(\mathrm{~min})$ & 0.503 & 3.35 & 0.745 \\
\hline CRITIC & 3.68 & 0.568 & 3.40 & 0.681 \\
\hline SPACE & 3.68 & 0.477 & 3.45 & 0.510 \\
\hline NEGOT & 3.50 & 0.598 & $3.20(\mathrm{~min})$ & 0.696 \\
\hline PARTIC & $3.86(\mathrm{max})$ & 0.468 & $3.70(\mathrm{max})$ & 0.571 \\
\hline
\end{tabular}

Finally, Table 4 shows the results for both groups combined, ordered from the highest to the lowest average value. We also include a classification level (high, intermediate or low), which is based the mean values but takes into account the standard deviations; this classification will be referred to in later analysis and discussion.

\begin{tabular}{|l|c|c|c|}
\hline \multicolumn{3}{|c|}{ Table 4: Results for All Students Combined } \\
\hline & \multicolumn{2}{|c|}{ All students } & \multirow{2}{*}{ Classification } \\
\cline { 2 - 3 } & Average value & Deviation & high (h) \\
\hline PARTIC & $3.80(\max )$ & 0.516 & \multirow{2}{*}{ intermediate (i) } \\
\hline SPACE & 3.60 & 0.496 & \\
\hline CRITIC & 3.55 & 0.630 & \multirow{2}{*}{ low (l) } \\
\hline LEARN & 3.50 & 0.641 & \multirow{2}{*}{0.628} \\
\hline NEGOT & 3.38 & 0.572 & \\
\hline KNOWL & $3.33(\mathrm{~min})$ & &
\end{tabular}

\section{Factor Analysis (FA) Validation and Results}

Factor analysis is commonly used to reveal or investigate underlying structures that may be contained within a data set, particularly when the researcher believes that responses to many different questions are driven by just a few underlying structures (factors). It is sometimes useful to explore differences between groups in terms of latent structure (Tabachnick \& Fidell, 2007). In this study we explore these latent structures in terms of association but not causality.

A Spearman correlation matrix found 4 out of 15 correlations $(27 \%)$ to be significant at the level of $\alpha=0.01$, which is sufficient to ensure an acceptable degree of multicollinearity. Bartlett's sphericity test (the non-null correlations, when taken jointly) was significant at a probability level of 0.001, making it suitable for factor analysis. Similarly, the Kaiser-Meyer-Olkin (KMO) sampling adequacy measurement value of 0.526 can be considered regular. Regarding the cumulative variance percentage criterion, three extracted factors would together explain $77 \%$ of the total variance, a satisfactory value for an investigation framed in Social Sciences. [If each variable contributes 1 to the total eigenvalue, and only those factors that explain at least one variable are considered, all the factors with latent roots lower than 1 (non-significant) will be rejected. This 
condition is fulfilled for three factors (latent root criterion).] Acceptable communality levels should be around 0.50 , so that most of the original information is contained or explained in at least half of the variance of each variable. This is known as the scree plot criterion (Hair, Anderson, Tatham, \& Black, 1991). In our study there was no factor below this figure, indicating that the data is suitable for factor analysis.

The method chosen in this work is the Varimax rotation, which focuses on simplifying the factor matrix columns. The objective is to explain a power level of 80 percent at a significance level of 0.05 and with standard errors of approximately twice the conventional correlation coefficients (Hair et al., 1991). Communality values above 0.75 are admitted as an acceptable level of explanation, since more than half of the variance of each variable is explained. The aim is to minimise the number of significant loads on each row and the factor matrix (one associated variable over a single factor). A variable with several high loads is a candidate for elimination.

The results of the factor analysis are shown in Table 5. Only the LEARNING variable does not reach the 0.75 value, although it comes close. When the results are interpreted, care will be taken in this regard. (Note: letters in parentheses refer to items in Classification column of Table 4.)

\begin{tabular}{|c|c|c|}
\hline \multicolumn{3}{|c|}{ Table 5: Factor Analysis Results } \\
\hline FACTOR 1 & FACTOR 2 & FACTOR 3 \\
\hline $\begin{array}{c}\text { (1) NEGOTIATION }(0.942) \\
\text { (i) CRITICISM }(0.814)\end{array}$ & $\begin{array}{c}\text { (h) PARTICIPATION }(0.891) \\
\text { (l) KNOWLEDGE }(0.820)\end{array}$ & $\begin{array}{c}\text { (i) SPACE }(0.846) \\
\text { (i) LEARNING }(-0.638)\end{array}$ \\
\hline
\end{tabular}

\section{Discussion}

\section{General Descriptors Results Analysis}

The mean values for all the variables (as shown in Tables 3 and 4) can be considered high, near the maximum possible value of four. However, higher scores were observed in all variables for the Teacher Training series when compared with the Master/Doctorate group (Table 3). We suggest that the higher attitudinal scores of the Teacher Training group are associated with the collaborative (small group) working methodology that they were exposed to. Synergeia would induce knowledge construction and sharing in the pupils, and open debates about negotiation and criticism.

In particular, the ability of the framework to foster participation (PARTIC) in knowledge society received the highest rating in both groups. In the Master/Doctorate group, the lowest rating was for the framework's ability to generate negotiation skills (NEGOT). This was to be expected, as their work dynamic in the classroom focused on individual work and effort, and the negotiation possibilities of Synergeia were not used. In the Trainee Teacher group, the variable least valued was the ability to construct knowledge (KNOWL). A more traditional view of knowledge construction might have been adopted by these students, one which is not as closely aligned with the objectives of the virtual learning framework. They could perhaps be termed creatures of their time, caught between tradition and the emerging world of ICTs. The Master/Doctorate score for the KNOWL variable was very similar, and was the second-lowest for their group after NEGOT.

\section{Factor Analysis Results Analysis}

Our interpretation of the results shown in Table 5 is provided below, based on the composition of the three factors. We do not attempt to establish causality between variables. 
Factor 1 or Epistemological Relativism: This factor relates to the ability to reach agreement through the negotiation of meaning, accompanied by the capacity to question and to engage constructively with criticism. It is construed here as the ability of students to reach agreement within the virtual platform: a theory is good if it has been negotiated previously. Mellado (1998a) developed a progression hypothesis of scientific knowledge among educators which encompasses three levels of epistemological conception.

- The first level corresponds to an epistemological conception of scientific knowledge of an "empiricist-positivist mechanist" nature. It can be characterised as being a reflection of an external reality that allows the possibility of objective knowledge and, therefore, of absolute and closed truths.

- The intermediate level which follows is characterised by the admission that there are no absolute truths, since knowledge changes and evolves; thus this level of epistemological conception recognises that there is certain relativism in terms of scientific truth. However, relativism is not accepted in relation to the method; educators at this level have faith in the scientific method, which is regarded as the only procedure to access the truth.

- Finally, there is an epistemological conception of a "relativist-constructivist" nature. Here, knowledge is seen as a construction that occurs in the subject-subject and subject-world interaction, thus being determined by both the properties of reality and those of the subject that constructs it. It is considered to be knowledge constructed in a process with a relative and evolutionary character and which is validated in the democratic negotiation and consensus of the criteria used to this end. This level seems to coincide most closely with the perceptions of our students.

Factor 2 or Methodological Relativism (Participate to Construct): The induction of students into the use of virtual spaces was a necessary condition for the construction of knowledge among the Teacher Training group: it is constructed only if it is participated. Wamba (2001) describes this type of conception of how Science is constructed as is occurs in teachers, which leads to a three-level progression hypothesis.

- On an initial level we would find what is known as "extreme empiricism". Here scientific knowledge is constructed by applying a specific scientific methodology, in which the empirical evidence of the data is used to prove or disprove the hypothesis as a model that reflects reality.

- Next, we would find an intermediate level, or "moderate empiricism". At this level the scientific method is recognised and the empirical evidence of the data is used to elaborate or extend the hypothesis, admitting that the theory guides the interpretation of the data.

- Finally we identify a reference level or "methodological relativism", where methodological diversity is accepted. The research begins by posing problems which in turn lead to a new set of problems, in an interactive process between different problems, hypotheses, theories and data gathering procedures. In addition, other elements such as ideology or personal experience may also play a role. This seems to be the level at which the perceptions of the students in this study are located.

Factor 3 or Relativised Virtual Teaching: There is an inverse relationship between the requirement to construct virtual spaces as students, and the likelihood of their subsequent implementation as educators. Both variables showed intermediate scores in the students' perceptions, which appears to indicate that their future use by the trainee teachers is not assured; at the very least it is not perceived as a fundamental need, which seems to tell us that the creation of such virtual work spaces is indeed valued positively, but is not the only resource available to facilitate learning. There are abundant examples in the literature of negative perceptions held by future teachers regarding the use of technological tools. This is mainly due to two fundamental issues: 
technical problems that need to be overcome during development; and the amount of time required for successful implementation. These obstacles may finally outweigh the undoubted benefits of the tools (of which the students as future educators are aware), such as the development of critical thinking skills and creativity (Heejung \& Wilder, 2010).

\section{Conclusion}

Throughout this work it has been shown how students' perceptions differ according to their use of the Synergeia learning framework, which is in line with the findings of Baker \& Lund (1997).

Firstly, the highest rating across both groups and all variables was for the Participation in Knowledge Society variable. The fact that the Teacher Training group scored even higher than the Master/Doctorate group may have been influenced by the fact that the teacher training course that was used for this study specifically involved collaborative learning, taking as reference the Active Learning Methodologies approach.

Another relevant aspect that emerged from students' attitudes to virtual cooperative learning environment was the evidence of underlying hypotheses in both groups:

a) Epistemological relativism adapted to the virtual world, where negotiation impregnates theory formulation (Mellado, 1998b).

b) The need to participate in order to build knowledge, closely related to the previous point (Weinberger \& Fischer, 2006).

c) A certain reticence towards virtual learning as the only teaching mechanism (Pearson, 1999).

Another aim of the work was to develop an effective instrument for evaluating attitudes towards virtual collaborative learning. Despite three decades of advances in information and communications technology (ICT) and a generation of research into cognition and new pedagogical strategies, the field of assessment has not progressed much (Clarke-Midura \& Dede, 2010). We proposed an instrument to assess the Synergeia telematic network which was implemented with future educators and its evaluation was found to be acceptable. We are aware that there is a feeling of "reservation" among educators (in our case future teachers) which was corroborated in this work, about how these platforms could affect their free time and the workload that it would impose upon them (Ligorio \& Van Veen, 2006). This aspect should not be neglected, as the notorious "digital illiteracy" barrier is lurking beneath the construction of the Europe of Knowledge. Some authors emphasise the need for continuous training in the use of ICT for teaching staff responsible for the training of future educators, given the exponential growth of the these technological tools (Muwanga-Zake, 2008). While we place our work on a micro level, its future implications are located in the meso. The participating students are future educators; their latent perceptions are likely to be transferred to their own students in the form of a hidden curriculum (Hargreaves, 2001) and, therefore, we must know about them (Wubbels, 1992). Other issues that need to be taken into account include the reinterpretation of original task designs by students, so that outcomes may differ radically from what was planned by the teachers (Arvaja, 2011), as well as the possibility that the collaborative process may itself present an obstacle to students (Kapur \& Kinzer, 2008).

Although the creation of the Synergeia framework is not recent, its uptake and use in the educational context for which it was created is still very limited, and its potential has yet to be explored and exploited. It has several advantages over other much more widespread virtual frameworks such as Moodle, particularly in the construction of shared knowledge. Synergeia has a stronger focus on distance training and can be combined with other platforms such as Wikis (Anguita, García, Villagrá, \& Jorrín, 2010), to create collaborative knowledge creation environments such as those used by open code communities. In turn, the free articulation of objectives and involvement of volunteers have been proven to foment productivity (Gerdes, 2010). 
This study has demonstrated that students appreciate using a collaborative tool and value the capacities it provides, both in the creation of new knowledge and the enabling of a critical attitude (Mahdizadeh, 2007). In addition, we have analysed the students' perceptions of how knowledge is constructed as well as the effects of negotiation and criticism, all of which was facilitated by the teaching-learning model that is embodied in the Synergeia virtual framework.

In a future course we shall try to introduce negotiation techniques among the new students on the Teaching and Doctorate courses. We intend to compare their perceptions to find out how they vary in the new context of negotiation and see how it affects knowledge construction, with the aim of observing differences in the way that some studies are carried out (Beers, Boshuizen, Kirschner, \& Gijselaers, 2007). We are aware of the advantages that are gained when negotiating techniques are introduced during knowledge construction and the influence they have on the development of critical thinking, even though the benefits to the student may not be immediately apparent (Carell \& Herrmann, 2009). Examining classroom innovation may shed light on the nature, design, and conditions for the emergence of collaboration in complex settings and extend our understanding of how socio-cognitive, cultural, and systemic forces impinge on collaboration (Chan, 2011). Our intention is to gather more data which can be used to establish theories based on the variables we have studied; for this purpose, we are currently developing a structural equation model that will be used to generate hypotheses about students' perceptions.

We are also interested in understanding changes in the attitudes of future teachers to the use of collaborative tools in education, and in identifying underlying obstacles to ICT use that might affect the professional development of future teachers (Vázquez-Bernal, Jiménez-Pérez, \& Mellado, 2008). In support of this goal, we are working towards defining the characteristics of a didactic instrument focusing on virtual frameworks and Web 2.0. This will be used to assess the attitudes of students in the early stages of teacher training, and to evaluate the impact of virtual courses that are put into practice during initial teacher training (Lorca, Vázquez-Bernal, Morón, \& Wamba, 2010).

\section{References}

Arvaja, M. (2011). Analyzing the contextual nature of collaborative activity. In Sadhana Putambekar, Gijsbert Erkens \& Cindy Hmelo-Silvers (Eds.), Analysing interactions in CSCL. Methods, approaches and issues (pp. 25-47). Utrecht: Springer.

Anguita, R., García, S., Villagrá, S., \& Jorrín, I. M. (2010). Wikis y aprendizaje colaborativo: lecciones aprendidas (y por aprender) en la facultad de educación. Red U - Revista de Docencia Universitaria. Número Monográfico $V$. Retrieved from http://www.um.es/ead/Red_U/m5

Baker, M., \& Lund, K. (1997). Promoting reflective interactions in a CSCL environment. Journal of Computer Assisted Learning, 13, 175-193.

Baghaei, N., Mitrovic, A., \& Irwin, W. (2007). Supporting collaborative learning and problem-solving in a constraint-based CSCL environment for UML class diagrams. International Journal of ComputerSupported Collaborative Learning, 5(3), 345-353.

Beers, P. J., Boshuizen, H. P. A., Kirschner, P. A., \& Gijselaers W. H. (2007). The analysis of negotiation of common ground in CSCL. Learning \& Instruction, 17(4), 427-435.

Bower, M., \& Richards, D. (2006). Collaborative learning: Some possibilities and limitations for students and teachers. In L. Markauskaite, P. Goodyear \& P. Reimann (Eds.). Proceedings of the 23rd Annual Conference of the Australasian Society for Computers in Learning in Tertiary Education: Who's learning? Whose technology? (pp. 79-89). Sydney: Sydney University Press.

Carell, A., \& Herrmann, T. (2009). Negotiation-tools in CSCL-scenarios - do they have a valid use? Proceedings of the 9th InternationalCconference on Computer Supported Collaborative Learning: Vol. 1 (pp. 557-566). Rhode, Greece: ISLS. 
Chan, C. K. K. (2011). Bridging research and practice: Implementing and sustaining knowledge building in Hong Kong classrooms. Computer-Supported Collaborative Learning, 6(2), 147-186.

Clarke-Midura, J., \& Dede, C. (2010). Assessment, technology, and change. Journal of Research on Technology in Education, 42(3), 309-328.

Ćukušić, M., Alfirevic, N., Granić, A., \& Garača, Ž. (2010). e-Learning process management and the elearning performance: Results of a European empirical study. Computers \& Education, 55(2), 554-565.

Dillenbourg, P. (1999a). What do you mean by “collaborative learning”? In P. Dillenbourg (Ed.), Collaborative learning: Cognitive and computational approaches (pp. 1-16). Amsterdam, NL: Pergamon, Elsevier Science.

Ertmer, P. A., \& Ottenbreit-Leftwich, A. T. (2010). Teacher technology change: How knowledge, confidence, beliefs, and culture intersect. Journal of Research on Technology in Education, 42(3), 255-284.

Ferreras, M., \& Wamba, A. M. (2008). Una propuesta de instrumento de evaluación continua: la rúbrica o plantilla de evaluación en la formación inicial del profesorado. In $\mathrm{M}^{\mathrm{a}}$ Rut Jiménez Liso (Ed.) Ciencias para el Mundo Contemporáneo y Formación del Profesorado en Didáctica de las Ciencias Experimentales (pp. 1166-1175). Almería: Universidad de Almería.

Gerdes, A. (2010). Revealing preconditions for trustful collaboration in CSCL. International Journal of Computer-Supported Collaborative Learning, 5(3), 345-353.

Kollias, V., Mamalougos, N., Vamvakoussi, X., Lakkala, M., \& Vosniadou, S. (2005). Teachers' attitudes to and beliefs about web-based collaborative learning environments in the context of an international implementation. Computers \& Education, 45(3), 295-315.

Koksal, M. S., \& Yaman, S. (2009). An analysis of Turkish prospective teachers' perceptions about technology in education. RELIEVE, 15(2), 1-10. Retrieved from http://www.uv.es/RELIEVE/v15n2/RELIEVEv15n2_3.ht

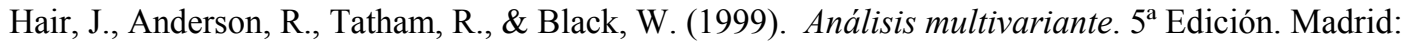
Prentice Hall.

Hargreaves, D. (2001). A capital theory of school effectiveness and improvement [1]. British Educational Research Journal, 27(4), 487-503.

Heejung, A., \& Wilder, H. (2010). A bottom-up approach for implementing electronic portfolios in a teacher education program. Journal of Digital Learning in Teacher Education, 26(3), 84-91.

Heo, H., Lim, K. Y., \& Kim, Y. (2010). Exploratory study on the patterns of online interaction and knowledge co-construction in project-based learning. Computers \& Education, 55(3), 1383-1392.

Huynh, M. Q., Lee, J.-M., \& Schuldt, B. A. (2005). The insiders' perspectives: A focus group study on gender issues in a computer-supported collaborative learning environment. Journal of Information Technology Education, 4, 237-255.

Jiménez, G., \& Llitjós, A. (2006). Deducción de calificaciones individuales en actividades cooperativas: una oportunidad para la coevaluación y la autoevaluación en la enseñanza de las ciencias. Revista Eureka sobre Enseñanza y Divulgación de las Ciencias, 3(2), 172-187.

Jiménez, G., Núñez, E., \& Llitjós, A. (2006). Synergeia, un entorno telemático cooperativo en el área de ciencias. Alambique, 50, 84-90.

Jones, C., \& Dirckinck-Holmfeld, L. (2009). Analysing networked learning practices. In L. DirckinckHolmfeld, C. Jones, \& B. Lindström (Eds.), Analysing networked learning practices in higher education and continuing professional development, technology-enhanced learning (pp. 10-27). Rotterdam: Sense Publishers.

Kapur, M., \& Kinzer, C. K. (2009). Productive failure in CSCL groups. International Journal of ComputerSupported Collaborative Learning, 4(1), 21-46. 
Kolodner J., \& Guzdial, M. (1996). Effects with and of CSCL: Tracking learning in a new paradigm. In: Koschmann T. (Ed.), CSCL: Theory and practices of an emerging paradigm (pp. 307-320). Hillsdale, NJ: Lawrence Erlbaum and Associates.

Lafifi, Y., \& Touil, G. (2010). Study of the impact of collaboration among teachers in a collaborative authoring system. Journal of Information Technology Education: Innovations in Practice, 9, 113 - 132. Retrieved from: http://www.jite.org/documents/Vol9/JITEv9IIPp113-132Lafifi784.pdf

Ligorio, M. B., \& Van Veen, K. (2006). Constructing a successful crossnational virtual learning environment in primary and secondary education. Association for the Advancement of Computing In Education Journal, 14(2), 103-128.

Liljenström, H., \& Svedin, U. (2005) Micro, meso, macro: Addressing complex systems. London: World Scientific Publishers.

Lipponen, L., Rahikainen, M., Hakkarainen, K., \& Palonen, T. (2002). Effective participation and discourse through a computer network: Investigating elementary students' computer-supported interaction. Journal of Educational Computing Research, 27, 353-382.

Lorca Marín, A. A., Vázquez-Bernal, B., Morón Monge, H., \& Wamba Aguado, A. M. (2010). Una aproximación docente a la Enseñanza a través de la Web 2.0 y/o entornos virtuales en la observación inicial del profesorado de Secundaria. In A. M. Abril \& A. Quesada (Eds.), XXIV Encuentro de Didáctica de las Ciencias Experimentales (pp. 110-117). Jaén: Servicio de Publicaciones de la Universidad de Jaén.

Ma, A. (2012). Evaluating how the computer-supported collaborative learning community fosters critical reflective practices. Interdisciplinary Journal of E-Learning and Learning Objects, 9, 52-75.

Mahdizadeh, H. (2007). Student collaboration and learning. Knowledge construction and participation in an asynchronous computersupported collaborative learning environment in higher education. Unpublished doctoral dissertation, Education and Competence Studies - Social Sciences Group, Wageningen University, The Netherlands.

Mellado, V. (1998a). The classroom practice of preservice teachers and their conceptions of teaching and learning science. Science Education, 82(2), 197-214.

Mellado, V. (1998b). Preservice teachers' clasrooms practice and their conceptions of the nature of science. In B. J. Fraser \& K Tobin (Eds.) International Handbook of Science Education (pp. 1093-1110). Dordrecht (The Netherlands): Kluwer Academic Publishers.

Mellado, V., Ruiz, C., Bermejo, M. L. \& Jiménez, R. (2006). Contributions from the philosophy of science to the education of science teachers. Science \& Education, 15(5), 419-445.

Mertler, Craig A. (2001). Designing scoring rubrics for your classroom. Practical Assessment, Research \& Evaluation, 7(25). Retrieved from http://PAREonline.net/getvn.asp?v=7\&n=2

Monereo, C. (2004). Internet, un espacio idóneo para desarrollar las competencias básicas. In Carles Monereo (Ed.) Internet y competencias básicas (pp. 5-26). Barcelona: Graó.

Morin, D., Thomas, J. D. E., \& Saadé, R. F. (2012). Activities and resources in online learning: From a critical thinking view. Proceedings of Informing Science \& IT Education Conference (InSITE) 2012, 597-602.

Muwanga-Zake, J. W. F. (2008). Framing professional development in information and communications technologies: University perspectives. Journal of Information Technology Education, 7, 285-298.

Pardo, A., Morales, F. J., \& Rodríguez López, J. M. (2009). El espacio Europeo de Educación Superior y la Metodología Activa. Huelva: Universidad de Huelva.

Pearson, J. (1999). Electronic networking in initial teacher education: Is a virtual faculty of education possible? Computers \& Education, 32(3), 221-238. 
Roschelle, J., \& Teasley, S. (1995). The construction of shared knowledge in collaborative problem solving. In C. O'Malley (Ed.), Computer-supported collaborative learning, 69-197. Berlin, Germany: Springer Verlag.

Rodríguez, J., Infante, A., \& Pardo, A. (2004). La teleformación. Apoyo al profesor universitario en su nuevo rol. Huelva: Universidad de Huelva.

Rubens, W. (2003). Samenwerkend leren met behulp van ICT. Informatiebulletin Vereniging Informatiekunde en Informatietechnologie in het Onderwijs, 15, 24-27.

Stahl, G., \& Hesse, F. (2009). Paradigms of shared knowledge. International Journal of ComputerSupported Collaborative Learning, 4(4), 365-369.

Stahl, G., Koschmann, T., \& Suthers, D. (2006). Computer-supported collaborative learning: An historical perspective. In R. K. Sawyer (Ed.) Cambridge handbook of the learning sciences (pp. 409-426). Cambridge, UK: Cambridge University Press.

Silveira Botelho, T., \& Madrid Vivar, D. (2009). As TIC na formação inicial da ESE João de Deus. Educação, Formação \& Tecnologias, vol. 2 n 2, 84-94. Retrieved from http://eft.educom.pt/index.php/eft/article/view/107/70

Smith, J. J., \& Greene, C. H. (2013). Pre-service teachers use e-learning technologies to enhance their learning. Journal of Information Technology Education, 2, 121-140.

Tabachnick, B., \& Fidell, L. S. (2007). Using multivariate statistics. 5th Ed. Boston: Allyn and Bacon.

van Aalst, J. (2009). Distinguishing knowledge-sharing, knowledge-construction, and knowledge-creation discourses. Computer-Supported Collaborative Learning, 4(3), 259-287.

Vázquez-Bernal. B. (2010). El uso de Synergeia como medio para el aprendizaje cooperativo. En "Metodología Activa en el Marco del EEES". Retrieved from http://hdl.handle.net/10272/3029

Vázquez-Bernal, B., Jiménez-Pérez, R., \& Mellado, V. (2008). The professional development of secondary education science teachers: A case study as methodological integration. In I. V. Erikson (Ed.), Science education in the 21st century (pp. 137-164). New York: Nova Science Publishers.

Wamba, A. M. (2001). Modelos didácticos y obstáculos para el desarrollo profesional: Estudios de caso con profesores de Ciencias Experimentales en Educación Secundaria. Michigan, USA: Proquest Information and Learning.

Weinberger, A., \& Fischer, F. (2006). A framework to analyze argumentative knowledge construction in computer-supported collaborative learning. Computers \& Education, 46(1), 71-95.

Wolcott, S. K. (2006, February 9). Steps for better thinking rubric. Retrieved from http://www.WolcottLynch.com.

Wubbels, T. (1992). Taking account of student teachers' preconceptions. Teaching and Teacher Education, $8(2), 137-149$. 


\section{Biographies}

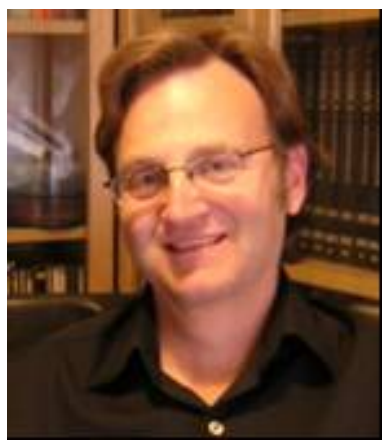

Bartolomé Vázquez-Bernal received a degree in Chemistry from University of Cádiz (Spain) and holds a PhD in Science Education from the University of Huelva, where he is Associate Professor in the Department of Science Education and Philosophy. He was also a member of the management team of the Association of Teachers and Researchers of Experimental Sciences (APICE in Spanish) in Spain. His field of research interest is focused on Training and Teacher Professional Development Experimental Sciences, the importance of Information Technology and Communication in Teacher Education, and the influence of Metacognition and Emotion in the processes of Teaching-Learning Experimental Science. He has published several papers on these topics and has participated in conferences and seminars. He is section editor of the Journal "Revista Eureka sobre Enseñanza y Divulgación de las Ciencias".

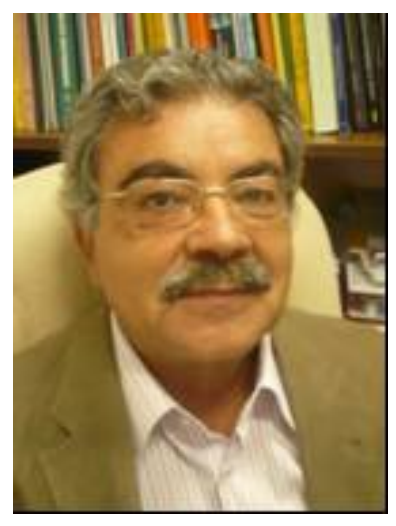

Roque Jiménez-Perez holds a Ph.D. in Inorganic Chemistry from the University of Seville, and is Professor of University Teaching Area Experimental Sciences. He was previously director of the Interuniversity Research Master's Degree in Teaching and Learning of Science (with distinction of National Quality and Excellence) in Spain. He was also President of the Association of Teachers and Researchers of Experimental Sciences in Spain. He has contributed to numerous national projects and is an international project evaluator, among others for the Ministry of Education of Argentina, Colombia and Mexico, and advisor to the ANEP . He has supervised a large number of Masters and Doctoral Theses and has had more than a hundred scientific papers published, many of them in prestigious international journals. He has served on the Editorial Board Advisory Council of the Journal "Enseñanza de las Ciencias" as well as several magazines. 